\title{
The Effect of Bank Specific and Macroeconomic Determinants of Banking Profitability: A Study on Bangladesh
}

\author{
Abu Hanifa Md. Noman ${ }^{1,2}$, Mustafa Manir Chowdhury ${ }^{2}$, Najneen Jahan Chowdhury ${ }^{2}$, Mohammad Jonaed Kabir ${ }^{2}$, \\ \& Sajeda Pervin ${ }^{3}$ \\ ${ }^{1}$ Department of Finance and Banking, Faculty of Business and Accountancy, University of Malaya, Malaysia \\ ${ }^{2}$ Department of Business Administration, International Islamic University Chittagong, Bangladesh \\ ${ }^{3}$ Department of Business Administration, BGC Trust University Bangladesh, Bangladesh \\ Corresponding: Abu Hanifa Md. Noman, Department of Finance and Banking, Faculty of Business and \\ Accountancy, University of Malaya, Malaysia. E-mail: kosiralam@yahoo.com,
}

Received: April 8, 2015

doi:10.5539/ijbm.v10n6p287
Accepted: April 16, $2015 \quad$ Online Published: May 22, 2015

URL: http://dx.doi.org/10.5539/ijbm.v10n6p287

\begin{abstract}
The study designed to investigate bank specific and macroeconomic determinants of profitability considering 299 observations of 35 banks in Bangladesh during 2003 to 2013. The investigation process considers all types of local Bangladeshi banks, OLS fixed effect and two step system GMM model. The results report that credit risk, cost efficiency, GDP growth and real interest rate effects profitability negatively; and capital adequacy, liquidity, size, inflation and stock market turnover effect profitability positively. The results further find that both development banks and private commercial banks are more profitable than public commercial banks in Bangladesh. Furthermore, the study finds that ROAA is most preferred measure of profitability. The study formulates some significant policy implications for improving the profitability of the banking sector of Bangladesh.
\end{abstract}

Keywords: banks, Bangladesh, fixed effect, generalized methods of moments, profit determinants, and profitability

\section{Introduction}

Banks, as financial institutions, play a vital role for bringing financial stability and economic growth through their expected contribution by mobilizing financial resources across the economy (Masood \& Ashraf, 2012). The role is more important for the developing economies with under developed capital market (Felix Ayadi et al., 2008; Zhang et al., 2013). A sound and profitable banking system is better able to improve financial system stability and economic growth as it makes the economy more endurable to negative and external shocks (Athanasoglou et al., 2008), on the other hand, insolvency of the system leads to economic crisis (Chaplinska, 2012; Fang et al., 2014; Fu et al., 2014). Moreover, profitability is considered as precondition for an innovative, productive and efficient banking system (Chen \& Liao, 2011). Therefore, investigation of the determinants of profitability is vital for the growth and stability of the whole economy. Considering the importance of banking profitability many studies have been conducted focusing both single country and cross country such as Hassan and Bashir (2003) 21 developing countries where islamic banking has been praticed, Samad (2004) for Bahrain, Kosmidou et al. (2005) for UK, Athanasoglou et al. (2008) for Greece, AL-Omar and AL-Mutairi (2008) for Kuwait, Heffernan and Fu (2008) for China, Wasiuzzaman and Tarmizi (2010) for Malaysia, Qin and Dickson (2012) for Tanzania, Wasiuzzaman and Gunasegavan (2013) for Malaysia, Francis (2013) for Sub Sahara Africa, Masood and Ashraf (2012) for twelve Muslim countries, Perera et al. (2013) for four South Asian courtiers in order to investigate the determinants of banking profitability. The studies reveal that both bank level and macro level factors are importantly determine the profitability of the banking system of a country.

Most of the studies focusing on banking profitability such as, Samad (2004), Kosmidou et al. (2005), AL-Omar and AL-Mutairi (2008), Qin and Dickson (2012), Francis (2013), Masood and Ashraf (2012), Perera et al. (2013) apply linear model in investigating the influence of the different determinants on the banking profitability. Although the studies explain meaningful analysis at certain level; a few issues are not handled sufficiently. Say for example, firstly, the literatures pay more focus on internal determinants of the banking profitability with a 
limited attention on the effect of macroeconomic factors on the profitability. Secondly, most of the study do not adequately explain econometric methodology and do not consider some features of the banking profit such as endogeneity and heteroscadesticity which make the results inconstant and bias. Thirdly, a certain type of bank may be more profitable than others and type of bank may influence of the profitability but it is ignored in the earlier literatures. Moreover, the previous studies consider short panel data consisting 5 to 6 years which provides also less strong results. In order to fulfill the above literature gap the study warrants to reinvestigate the determinants of the profitability considering more macroeconomic variable along with influential bank specific variables, applying detailed econometric methodology, considering type of banks and including more data in the panel.

In the reinvestigation process of banking profitability determinants, banking sector of Bangladesh provides an excellent context which consists of 56 banks including 4 state owned commercial banks, 4 development banks, 39 private commercial banks and 9 foreign commercial banks with 8685 branches across the country. Here, banking plays a vibrant role for ensuring sustainable economic growth with continuously six percent plus gross domestic product in last decade by expanding its network to rural Bangladesh. Liberalization and globalization in the banking industry brought advancement in technical adoption, quality and quantity in banking operations in the country in recent years. These changes improve the performance of the banking sector. However, to the best of the knowledge of the researchers no earlier study focus on the profitability aspects of the banking sector of Bangladesh. Therefore, the study aims at reinvestigating the determinants of the profitability of the banking sector of Bangladesh during 2003 to 2013. The study further investigates whether banking type influence on the profitability of the banks in Bangladesh.

The study is decomposed in the following way. Section II details review of past studies regarding the determinants of profitability and different of profit proxies. Sector II explains methodology of the study in a systematic way. Section III reports and analyzes the results of the study and finally conclusion and recommendation of the study explained in the sector IV.

\section{Literature Review}

Numerous studies have been undertaken focusing on banking profitability specially internal and external determinants considering both cross country and single country. The first group includes (Athanasoglou et al., 2008); Francis, 2013; Masood \& Ashraf, 2012; Perera et al., 2013). The second group includes (AL-Omar and AL-Mutairi (2008); Athanasoglou et al. (2008); Heffernan and Fu (2008). The second group mainly conducts their research based on developing economies. Where, different studies uses different measures as profit proxy such as Athanasoglou et al. (2008); Francis (2013); Heffernan and Fu (2008); Perera et al. (2013) consider Return on Average Assets, henceforth, ROAA which is the ratio of net profit to average assets. It is also a good indicator of a bank's financial performance and managerial efficiency. The ratio is expressed as a percentage of total average assets. This ratio displays how efficiently a company is utilizing its assets and is also useful to facilitate comparison among peers in the same industry. Moreover, Masood and Ashraf (2012) considers Return on Average Equity, hence forth, ROAE which is the ratio of net profit to share holders average equity. This is also a good indicator of a bank's financial performance and managerial efficiency. It shows how competent the management is in using shareholders' equity for generating net profit. In addition, Chortareas et al. (2012); Heffernan and Fu (2008); Lee et al. (2014); Nguyen (2012) consider Net Interest Margin (NIM) as the indicator of profitability of the bank which is the ratio of the net interest to the amount of the earning assets. Higher the ratio is the indication of the better assets management quality for using the assets in profitable way.

Bank profitability is the function of both internal and external determinants. Internal determinants are the bank specific factors that are mainly affected by bank management decisions such as bank size, capital adequacy, risk management, liquidity management, operating efficiency. External determinants are both industry specific and macro-economic factors that reflect the economic and legal environment. Industry specific determinants describe industry structure variables that influence on bank profitability which is not directly affected by managerial decision. Industry specific variables include industry concentration and ownership structure of the bank. Macro-economic variables include economic growth and inflation.

Bank size provides the evidence of economies or diseconomies of scale in banking. Athanasoglou et al. (2008); Masood and Ashraf (2012); Perera et al. (2013) find that the effect of bank size on profitability is positive and significant statistically, while the relationship is linear. Moreover, AL-Omar and AL-Mutairi (2008) argues that positive effect of bank size on profitability reflects scale efficiency. On the other hand, Athanasoglou et al. (2008) considers relationship between size and profitability as non-linear arguing that the effect of size could be negative due to bureaucratic and other reason. He finds that the estimated effect of bank size does not provide 
evidence of economies of scale in banking.

Bank capital adequacy is another important bank specific determinant of profitability. Athanasoglou et al. (2008); Masood and Ashraf (2012); Wasiuzzaman and Gunasegavan (2013) and Perera et al. (2013) find that bank capital adequacy associates with bank profitability significantly and positively. These results authenticate the fact that well-capitalized banks can source deposits and other funding at low cost and pursue business opportunities more effectively and has more time and flexibility to deal with problems arising from unexpected losses, thereby increase profitability. However, Masood and Ashraf (2012) finds the capital adequacy highly significant and negatively relates with return on equity. Moreover, Qin and Dickson (2012) finds that capital structure has a negative determinant on profitability. High capital adequacy may lead of low profitability if investors are rigid to make great investment to avoid the losses in future where as it leads to high profitability if banks can avoid the payment of fixed interest expenses but dividends payments is optional can be paid or not paid.

Risk management is another important determinant of bank profitability. Risk is involved in every banking operation due to its nature. A bank may be failed due to low liquidity and poor assets quality. Therefore, bank risk may be grouped in to credit risk, liquidity risk, Market risk and operational risk. Among others, Athanasoglou et al. (2008) and Masood and Ashraf (2012) find that credit risk affect profitability negatively and significantly. This may imply that the tendency of commercial bank to exposure high risk loan generates more unpaid loan resulting these loan loss produces low profit to the commercial banks. Moreover, Francis (2013) finds liquidity is significantly and negatively related to profitability as higher liquid assets reduce the ability of banks to generate income. On the other hand Masood and Ashraf (2012) shows that liquidity has no effect or less effect on profitability.

Bank expenses management is also considered as another important determinant of bank profitability as it relates to managerial efficiency. Athanasoglou et al. (2008) and Heffernan and $\mathrm{Fu}(2008)$ establishes operating expenses are negatively and strongly relate to the bank profitability. More recently, Masood and Ashraf (2012) also finds that operational expense ratio is negatively associated to bank profitability. It implies that cost decisions of a bank management are instrumental in influencing its performance.

Now, spinning to the external determinants of bank profitability. It is noted that control variables can be classified to the factors that represent market characteristics such as concentration, ownership and industry size and the factors that represent the macro economy such as inflation, GDP per capita. Ownership status is mainly concerned to determine whether the bank is publicly or privately owned. Perera et al. (2013) argues public banks may have other than simply profit consideration which is consistent with the finding of Kosmidou et al. (2005). Athanasoglou et al. (2008), among others, found that the relationship between ownership and profitability is not significant.

Market structure also influences on profitability. Higher concentration ratio leads to higher profitability of the bank which is termed as Structure Performance Hypothesis. The firms with large market shares and well-differentiated products are able to exercise market power and earn noncompetitive profits, Samad (2008) reports that the profitability of the bank is dependent upon the market structure and the level of competition. Lower the level of competition in the market, higher the economic rent for a firm. Perera et al. (2013) finds that concentration affect bank profitability positively, whereas, Athanasogluou et al. (2008) initiates that the concentration affects the bank profitability negatively but the effect is insignificant. Moreover, Kosmidou (2008) finds that concentration affects the bank profitability also negatively but effect is significant.

Macro-economic control variables are the last group of bank profitability determinants. Macro-economic factors are real GDP growth rate, Inflation rate, Long term interest rate, Business Cycle. Athanasoglou et al. (2008) found that inflation and business cycle have positive effect on the profitability. However, Heffernan \& Fu (2008), and Masood and Ashraf (2012) observe that inflation is not significant to bank profit. Moreover, Francis (2013) reports that GDP growth rate and inflation rate affect bank profit negatively. Nevertheless, Masood \& Muhammed (2012) finds that GDP growth effect bank profit if ROE is considered as profit proxy. Recently, Perera et al. (2013) has made an attempt to identify the effect of control of corruption and rule of law on the profitability for South Asian Countries. As law and order not only affects foreign investment of those countries but also domestic businesses suffers as well if government fails to enforce the contracts due to corruption. They found that slack legal systems in those countries positively affect profitability as banks probably require high risk premiums on their loan contracts. 


\section{Materials and Methods}

\subsection{Variable Section}

This study uses financial ratios for evaluating the performance of the banking sectors of Bangladesh. The use of ratio in measuring performance is common in the literatures of finance and accounting practices which is evident from the previous studies such as among the others (Athanasoglou et al. (2008); Francis (2013); Heffernan and $\mathrm{Fu}$ (2008); Perera et al. (2013)). The greatest advantage of using ratio for measuring banks' performance is that it compensates bank disparities created by bank size (Samad, 2004). The study has considered all together twelve financial ratios of which three measure profitability, five measure bank characteristics and four measure macroeconomic condition of the country which are explained below:

The study considers three measures of profitability as dependent variables which are Return of Average Assets (ROAA) as ratio of net income to average assets, Return of Average Equity (ROAE) as ratio of net income to average equity and Net Interest Margin (NIM) as the indicator of profitability of the bank which is the ratio of the net interest to the amount of the earning assets.

The explanatory variables of the study include both bank level variables and macro economic variables. Bank level variables are credit risk, liquidity, capital adequacy, bank size and cost efficiency; and macro economic variables are real GDP growth rate, inflation rate, real interest rate and stock market turnover.

We measure credit risk as a ratio of loan loss reserve to gross loan (LLRGL). Theory implies that firm profitability is negatively associated with the high exposure to the credit risk. Therefore, we expect a negative relationship between profitability and credit risk; and banks need to improve the profitability by prudent credit risk management such as enhancing screening and monitoring the risk. Moreover, the central bank determines the policy for the banking industry regarding the level of loan loss reserve. Considering the policy bank management determines the reserve level for loan loss at the beginning of the period.

In addition we consider the ratio of equity to total assets (ETA) as capitalization ratio. It measures the bank's ability to absorb loss and exhibits how equity influences on banks profitability. The ratio does not only represent banks higher capital adequacy of the bank but also reduce risk and regulatory cost. Higher the ratio is the indication of the bank is running with profitable investment opportunity and lower the ratio indicates that bank is suffering from capital adequacy problem. The expected effect of ETA may be positive or negative.

Moreover, we consider the ratio of net loan to total assets as a proxy of bank's liquidity. Loan constitutes the largest interest earning assets of the bank and expects to effects profitability positively. If major segment of the deposit is used for loan creation, it is expected that the ratio increases interest income and effects profitability positively. However, high ratio may reduce liquidity level of the banks which may increase funding cost and also increase the credit risk of the bank. In that case, the effect of liquidity ratio may be negative. Therefore, the expected relationship between liquidity and profitability is unclear.

Cost to income (CI) ratio indicates the operational efficiency of the bank indicating the cost of running the bank in compare to it's income. Higher the ratio means that bank is operating at low efficiency and at high competition which negatively affects the profitability of the bank. Therefore, we expect a negative relationship between the $\mathrm{CI}$ ratio and profitability.

The size of the bank effects the bank profitability but it remains unclear the optimum level of bank size. Because, it is proven that the effect of growing size is positive but the sign may change due to rise of inefficiency and bureaucracy with the increase of bank size. Therefore, the effect of bank size also remains unclear. We consider bank size as the natural logarithm of total assets.

Now we are turning to the control variable. We consider some macroeconomic factors as control variable to control for external factors that determine profitability which is warranted in order to isolate the effect of bank characteristics on profitability. We consider here four macroeconomic variable which are considered as external to the banks such as real GDP per capita, inflation rate, real interest rate and stock market turnover.

The first macroeconomic variable real GDP per capita is expected to affect the banking profitability positively by influencing the factors which indirectly affect the demand and supply of loan and deposit conditions. Such as during the recession when GDP growth rate slowdown, the deposit mobilization, loan creation and credit quality decline which downsize the profitability of the banks.

The inflation rate is considered as the proxy of how macroeconomic risk affects the profitability of the bank. Here we use annual inflation rate based on consumer price index which estimates increase in consumer price index for all goods and services in percentage. 
Turnover ratio is the total value of shares traded during the period divided by the average market capitalization for the period. Average market capitalization is calculated as the average of the end-of-period values for the current period and the previous period. High inflation rate is related to both high income and high cost(Wasiuzzaman \& Tarmizi, 2010). If rise in income exceeds cost, inflation is expected to affect the profitability positively.

High real interest rate increases the loan interest rate which leads to affect the profitability positively (Hassan \& Bashir, 2003). Moreover, high real interest rate may also increase Islamic banks' profitability if large portion of the income comes from direct investment (Wasiuzzaman \& Tarmizi, 2010). However, high real interest rate influences profitability negatively too if higher loan interest rate reduces the demand of the banking loan. Moreover, market turnover is the indicator of business cycle movement of the country which may also influence on the profitability of the banks. It may affect the profitability positively.

There are three types of local banks in Bangladesh such as public commercial banks, development and private commercial banks with distinct objectives. The divergent objectives of the banks may influence on profitability. To capture this aspect we consider two dummy variables for development banks and private commercial banks. We compare both type of banks with public commercial banks. Hence, D_i indicates dummy for type of banks where $i$ is the type of bank which takes the value one and two for development bank and private commercial bank. These dummy variables show the relative performance of development banks and private commercial banks to public commercial banks in term of profitability.

\subsection{Model Specification}

In order to investigate the effect of bank specific and macroeconomic effect on banking profitability of Bangladesh we use the following basic panel linear regression model:

$$
Y_{i t}=c+\sum \beta_{i t} X_{i t}+\sum \gamma_{i t} Z_{i t}+\alpha_{\mathrm{i}} \mathrm{DB}_{\mathrm{i}}+\varepsilon_{\mathrm{it}}
$$

Where subscript $\mathrm{i}$ indicates individual bank and $\mathrm{t}$ indicates time period. The dependent variable Yit indicates profitability, the regressors Xit is the vector of bank specific variables, Zit is the vector of macroeconomic variables and Di indicates dummy variable for bank types. Moreover, and eit is the disturbance or error term, which expresses the effect of all other variables except for the independent variables on the dependent variable that we use in the function. We consider three profit proxies based on literature review which are return on average assets (ROAA), return on average equity (ROAE) and net interest margin (NIM). Moreover, the explanatory variable $\mathrm{X}$ is used for indicating bank specific variables which are expected to affect profitability of banks. Here the investigation process considers five bank specific factors based on extensive literature review which are loan loss reserve to gross loan ratio (LLRGL) as credit risk indicator, equity to total assets ratio (ETA) as capital adequacy or leverage ratio, cost to income ratio (CI) as cost efficiency, loan to total assets (LTA) as liquidity ratio and natural logarithm of total assets (lnTA) as size of the bank. We include some macroeconomic variables which are real GDP growth rate (GDP), inflation rate (INF), real interest rate (RIR) and stock market turnover (STV). In order to discern the relative performance of the types of banks in Bangladesh we also include two dummy variables such as D1 for specialized development banks and D2 for private commercial banks. Here we compare the relative performance of specialized development bank and private commercial banks with public commercial banks in Bangladesh.

The ordinary least square (OLS) is used in the study for identifying the relationship due to the advantage of yielding the best fit of coefficient for the future prediction provided that all the assumptions are met (Molyneux et al., 2013). There are three competing formulations of OLS models which are pooled model, fixed effect model and random effect model with respect to handing error terms. Pool model ignores the panel nature of data and considers error term as identically and independently distributed and uncorrelated with regressors where as, fixed effect model considers unobserved firm specific effects which are not included in the regression is correlated with the regressors while random effect model considers as this intercept effect is uncorrelated with regressors. In order to decide the right model there are two basic tests where first one is Breuch-Pagan test which is used to discriminate between Pooled model and Random effect model. Second test is Hausman test to decide between fixed effect and random effect model to be used. However, most important econometric concerns in analyzing banking data are dynamic nature of bank variables, heteroscadasticity and endogeneity of some exogenous variables (Liu et al., 2014; Schaeck \& Cihák, 2014). Therefore, in order to handle the potential dynamic nature of explanatory variables we have also used GMM (Generalized Methods of Moments) as it can also consider econometric concerns for unobserved bank level heterogeneity, potential endogeneity and autoregressiveness in the data on the behavior of dependent variables (Cubillas \& Suárez, 2013). We particularly use a two-step GMM system and specify the robust estimator of the variance-covariance matrix which is an alternative of GMM 
proposed by Jaffar and Musa (2014) and developed by Jaffar and Musa (2014) and modified by Azmat et al. (2014). We also have used fixed effect model based on the result of firstly Breuch-Pagan test and secondly Hausman test as an alternative model for ensuring robustness of the results.

\subsection{Data}

In order to investigate the determinants of the banking sector profitability of Bangladesh we have used both bank specific data and macroeconomic data where, the bank specific data have been collected from Bankscope database and macroeconomic data have been collected from the world bank database from the period of 2003 to 2013. There are 56 banks in Bangladesh including 4 stateowned commercial banks, 4 specialized development banks, 39 local private commercial bank and 9 foreign commercial banks. We ignor 9 newly established banks in our analysis which has been started their operations during 2013. We also have omitted foreign commercial banks due to unavailability of required data in the Bankscope database. Therefore, our sample consists 38 banks with 299 observations representing 68 percent of total banking assets of the country including 4 state own commercial banks, 4 specialized development banks and 30 private local commercial banks. We use econometric software package stata for processing our results.

\section{Results and Discussion}

The table 1 presents the mean, standard deviation, maximum and minimum value of the performance measures of the banks in Bangladesh. Here, the means of NIM, ROAA and ROAE are 3.32, 0.84 and 21.40 respectively indicating the better overall performance of the banks in Bangladesh.

Table 1. Descriptive statistics of the variables of interest

\begin{tabular}{lllll}
\hline Variable & Mean & Std. Dev. & Min & Max \\
\hline NIM & 3.32 & 1.68 & -6.4 & 7.88 \\
ROAA & .84 & 2.70 & -21.97 & 6.06 \\
ROAE & 21.40 & 59.62 & -176.08 & 850.24 \\
LLRGL & 5.31 & 5.88 & .77 & 42.38 \\
ETA & 6.82 & 14.19 & -92.1 & 66.51 \\
LTA & 64.1 & 12.88 & 3.81 & 91.13 \\
CI & 59.20 & 70.92 & 15.24 & 691.67 \\
lnTA & 13.84 & .97 & 11.02 & 16.12 \\
GDP & 6.07 & .59 & 5 & 7.1 \\
INF & 7.64 & 1.58 & 5.4 & 10.7 \\
RIR & 6.12 & 3.75 & -5.5 & 11 \\
STV & 89.31 & 57.25 & 23.2 & 212.6 \\
D1(Bank type dummy 1, 1 development bank, 0 otherwise) & .12 & .32 & 0 & 1 \\
D2(Bank type dummy 2, 1 private commercial bank, 0 otherwise) & .75 & .43 & 0 & 1 \\
\hline
\end{tabular}

Where, NIM stands for net interest margin, ROAA stands for Return of Average Assets, ROAE stands for Return of Average Equity, LLRGL stands for the ratio of loan loss reserve to gross loan, ETA stands for the ratio of equity to total assets, LTA stands for loan to total assets, CI stands for cost to income ratio, lnTA stands for natural logarithm of total assets, GDP stands for gross domestic production, INF stands for inflation rate, RIR stands for real interest rate, STV stands for stock market turnover.

The mean performance of public banks and development banks is roughly same but the performance of private commercial banks is quiet better than both public commercial banks and development banks. The standard deviation of dummies for type of the banks indicating that the performance of all public banks and development banks is roughly same but it varies among the private commercial banks. Before going for the analysis of the performance we run Pearson's correlation test in order to check multicolinearity among the explanatory variables. Table 2 reports the Pearson's correlation coefficient matrix. 
Table 2. Correlation matrix of the explanatory variable

\begin{tabular}{llllllllllll}
\hline & LLRGL & ETA & LTA & C/I & lnTA & GDP & INF & RIR & STV & D2 & D3 \\
\hline LLRGL & 1.00 & & & & & & & & & & \\
ETA & $-0.13^{*}$ & 1.00 & & & & & & & & & \\
LTA & $-0.28^{*}$ & $-0.25^{*}$ & 1.00 & & & & & & & & \\
C/I & $0.25^{*}$ & $-0.4^{*}$ & -0.01 & 1.00 & & & & & & & \\
lnTA & $-0.21^{*}$ & -0.09 & $-0.17^{*}$ & $0.15^{*}$ & 1.00 & & & & & & \\
GDP & 0.01 & -0.04 & -0.01 & 0.08 & 0.00 & 1.00 & & & & & \\
INF & -0.04 & 0.02 & 0.04 & -0.01 & 0.08 & $0.55^{*}$ & 1.00 & & & \\
RIR & 0.06 & 0.01 & -0.03 & 0.04 & -0.11 & $-0.27^{*}$ & 0.02 & 1.00 & & & \\
STV & -0.04 & 0.10 & 0.07 & $-0.13^{*}$ & 0.11 & $-0.51^{*}$ & -0.03 & $0.17 *$ & 1.00 & & \\
D1 & $0.30^{*}$ & $0.16^{*}$ & -0.01 & $0.28^{*}$ & $-0.22^{*}$ & -0.00 & -0.04 & 0.05 & -0.04 & 1.00 & \\
D2 & $-0.48^{*}$ & -0.04 & $0.16^{*}$ & $-0.35^{*}$ & $-0.17^{*}$ & -0.01 & 0.03 & -0.05 & 0.04 & $-0.63^{*}$ & 1.00 \\
\hline
\end{tabular}

*Correlation coefficient value is significant at $5 \%$. Where, NIM stands for net interest margin, ROAA stands for Return of Average Assets, ROAE stands for Return of Average Equity, LLRGL stands for the ratio of loan loss reserve to gross loan, ETA stands for the ratio of equity to total assets, LTA stands for loan to total assets, CI stands for cost to income ratio, lnTA stands for natural logarithm of total assets, GDP stands for gross domestic production, INF stands for inflation rate, RIR stands for real interest rate, STV stands for stock market turnover.

The Table 2 reports that the variables are free from the multi-colinearity problem, hence expecting the unbiased estimation from the data analysis.

Breusch and Pagan Lagrangian multiplier test statistics is rejected with high Chi square value (5.64) and probability value $(0.00)$ indicating that panel model is more efficient and appropriate than pool model. In order to decide between OLS fixed effect and random effect model, Hausman test with null hypothesis the difference in coefficients not systematic is conducted. High Chi-square value (69.9) and probability value (0.00) reject Hausman test and indicating that fixed effect OLS model should be used.

Table 3 exhibits empirical results based on OLS fixed effect and two step system GMM for the panel data of 299 observations of 35 banks in Bangladesh. The results based on both OLS fixed effect model and GMM indicate the correct specification of the models and best overall results. In case of OLS fixed effect model, significance of F statistics conforms the presence of significant individual effects indicating the appropriateness of OLS fixed effect. Moreover, In case of GMM, insignificant value of Hansen test and significant value of Sargan test based on probability value imply the model is not suffering from the over identification problem while the significant value of Wald test and more number of observation than that of number of instruments conforms the true value of the parameters, goodness of fit and correct specification of the GMM model. In addition, significant value of AR(1) and insignificant value AR(2) imply that null of no first order auto correlation is rejected and null of second order auto correlation can not be rejected which are expected from the GMM model for ensuring that the original disturbance terms are not serially correlated and unbiased results. As we discussed OLS fixed effect model suffers from certain limitations and two step system GMM overcomes those, our analysis is primarily based on GMM specifications. We also use OLS fixed effect model for ensuring the robustness of the GMM results.

Table 3. Regression output of OLS fixed effect model and two step system GMM model

\begin{tabular}{lllllll}
\hline Model & OLS-Fixed effect & \multicolumn{5}{l}{ Two step GMM System } \\
\hline $\begin{array}{l}\text { Dep. } \\
\text { Variables }\end{array}$ & ROAA & ROAE & NIM & ROAA & ROAE & NIM \\
\hline Constant & $9.40(2.7)^{* * *}$ & $91.79(54.02)^{*}$ & -7.31 & $2.23(2.53)$ & 76.5262 .64 & $-13.43(3.63)^{* * *}$ \\
& & & $(2.40)^{* * *}$ & & & \\
LLRGL & $-.09(.03)^{* * *}$ & $-1.88(.673)^{* * *}$ & $.00(.03)$ & $-.20(.04)^{* * *}$ & $-.86(.40)^{* *}$ & $.08(.04)^{* *}$ \\
ETA & $-.02(.01)$ & $-.09(.27)$ & $.018(.01)$ & $.05(.02)^{* * *}$ & $.00(.09)$ & $.05(.02)^{* * *}$ \\
LTA & $-.02(.00)$ & $.09(.18)$ & $-.02(.01)^{*}$ & $.01(.01)$ & $.01(.10)$ & $.05(.02)^{* * *}$ \\
CI & $-.02(.00)^{* * *}$ & $.22(.04)^{* * *}$ & $-.00(.00)^{* * *}$ & $-.01(.00)^{* * *}$ & $.141(.02)^{* * *}$ & $-.01(.00)^{* * *}$ \\
lnTA & $.17(.17)$ & $-5.59(3.38)^{*}$ & $.84(.14)^{* * *}$ & $.29(.16)^{*}$ & $-6.33(2.50)^{* * *}$ & $.84(.20)^{* * *}$ \\
D1 & & & & $2.11(.89)^{* *}$ & $-33.53(28.58)$ & $.74(1.16)$ \\
D2 & & & & $.19(.73)$ & $.95(9.22)$ & $1.31(.70)^{*}$ \\
\hline
\end{tabular}




\begin{tabular}{lllllll}
\hline GDP & $-.85(.2)^{* * *}$ & $-4.46(3.91)$ & $-.04(.17)$ & $-.55(.07)^{* * *}$ & $-4.36(.78)^{* * *}$ & $.07(.07)$ \\
INF & $.23(.06)^{* * *}$ & $2.65(1.19)^{* *}$ & $.08(.05)$ & $.11(.01)^{* * *}$ & $2.58(.19)^{* * *}$ & $-.01(.02)$ \\
RIR & $-.05(.02)^{* *}$ & $-.71(.471)$ & $-.03(.02)^{*}$ & $-.01(.01)$ & $-.71(.13)^{* * *}$ & $-.03(.01)^{* *}$ \\
STV & $.01(.00)$ & $.07(.03)^{* *}$ & $.01(.00)^{* * *}$ & $.00(.00)$ & $.06(.02)^{* * *}$ & $.00(.00)^{* *}$ \\
\multicolumn{1}{r}{$R^{2}$} & 0.32 & 0.11 & 0.12 & & & \\
Wald chi2(5) & & & & $2706.19 * * *$ & $876.68 * * *$ & $3409.53^{* * *}$ \\
F & $13.35(10,204)^{* * *}$ & $5.11(10,204)^{* * *}$ & 9.61 & & & \\
& & & $(10,202)^{* * *}$ & & & 248 \\
Observations & & & & 250 & 250 & 242 \\
Instrument & & & & 244 & 244 & 20.00 \\
Hasen chi2 & & & & -2.06 .52 & 29.26 & $-2.32 * * *$ \\
AR(1) & & & & 0.24 & 1.51 & 1.17 \\
AR(2) & & & & $523.73 * * *$ & $315.31 * * *$ & $73.94 * * *$ \\
Sargan test & & & & & & \\
\hline
\end{tabular}

Note. The table presents OLS fixed effect and two step system GMM model output which is based on equation (1). The analysis uses an unbalance panel data of 35 banks over 11 years which satisfies the condition of small time period and large number of banks in order to use GMM model. The values in the table indicate the coefficient of the variables and the values within parenthesis indicate standard error of the estimates. Moreover, * $* *$ and $* * *$ indicate significant of the coefficient value at $10 \%, 5 \%$ and $1 \%$ respectively. We consider NIM for net interest margin, ROAA for Return of Average Assets, ROAE for Return of Average Equity, LLRGL for the ratio of loan loss reserve to gross loan, ETA for the ratio of equity to total assets, LTA for loan to total assets, CI for cost to income ratio, lnTA for natural logarithm of total assets, GDP for gross domestic production, INF for inflation rate, RIR for real interest rate, STV for stock market turnover. D1 is the dummy for development banks which consider 1 if the bank is a development bank other wise 0 and $\mathrm{D} 2$ is the dummy for private commercial bank which takes value 1 if the bank is private commercial bank otherwise 0 . Significant value of F statistics indicates the joint significance of all explanatory variables. Significant value of Sargan test and insignificant value of Hansen test imply the joint validity of the instruments in GMM models. Significant value of AR(1) and insignificant value AR(2) ensure the absence of both first order and second order serial correlation. Moreover, significant value of wald test imply the goodness of fit of the GMM models.

The loan loss reserve ratio is negatively and significantly effects on both ROAA and ROAE except NIM which is expected as credit risk is negatively related to the profitability of the banks. The results support Choon et al. (2012); Kolapo et al. (2012); Sufian (2009); Wasiuzzaman and Tarmizi (2010) who find similar results. The results imply that the net profit of the bank reduces as banks use more buffer against credit risk. The beta coefficient of the estimate shows that every one unit increases in loan loss reserve decreases return on ROAA by 0.20 units and ROAE by 0.86 units while increases NIM by 0.08 unit. The GMM results consistent with alternative OLS fixed models. One explanation could be that risk appetites of the among the banks divergent and banks taking more risk may reap immediate high profit margin but at the same time have to keep provision as buffer against large default. Some banks may find a few loan turns to bad which reduces profit margin. Therefore, prudential credit risk management is necessary for the banks in order to improve the profitability of the bank.

Capitalization or leverage ratio indicates the capital stability of the bank. In GMM specification ETA ratio is positively and significantly related to the ROAA and NIM while it effects positively and insignificantly on ROAA which support the earlier study of Athanasoglou et al. (2008); Berger (1995); Kosmidou et al. (2005) who argue that lower ETA ratio is the indication of lower agency cost and higher performance. Moreover, Wasiuzzaman and Tarmizi (2010) argues that lower ETA ratio indication of high efficiency of bank performance. The results indicate that capital stability of the banks in Bangladesh is satisfactory which lead them to be efficient and profitable. The beta coefficient of ETA implies that one unit increases in the ratio increases ROAA by 0.05 unit, ROAE by 0.001 unit and NIM by 0.05 unit. However, OLS fixed effect estimation shows different results the effect of ETA on ROAA and ROAE due to the presence of heteroscedasticity among the data. But it is consistent with Hassan and Bashir (2003); Wasiuzzaman and Tarmizi (2010).

Liquidity ratio shows a positive relationship with all the performance measures of the banks of Bangladesh while the effect is significant only in case of NIM. The results indicate a positive correlation of the loan and bank performance implying that higher deposit transmission in to loan generates more profit for the banks in Bangladesh. The result is consistent with the findings of (Hassan and Bashir (2003); Wasiuzzaman and Tarmizi (2010)). The beta coefficient of LTA indicates that one unit increase in LTA increases ROAA by 0.01 unit, ROAE by 0.01 unit and NIM by 0.05 units. However, OLS fixed effect specification provides a different results which show that LTA effects negatively on ROAA and NIM but positive on ROAE which is consistent with Choon et al. (2012); Heffernan and Fu (2008); Kosmidou et al. (2005). This may be due to high competition in the credit 
market and divergent ability of the banks for generating profit from the credit operations in Bangladesh.

Cost to income ratio indicates the cost efficiency of the banks. The results shows that CI ratio is negative and significant with all performance measures except ROAE implying that more efficient bank in cost management makes more profit. The CI ratio is positive with both ROAA and NIM but negative with ROAE suggesting that holding more equity as capital buffer against credit risk may result in lost profit opportunity. The result is consistent with Heffernan and $\mathrm{Fu}$ (2008); Kosmidou et al. (2005). The result is found robust in alternative specification.

Next we find natural log of total assets effects profitability positively and significantly in GMM specification except ROAE. It affects ROAA and NIM positively while affects ROAE negatively which implies that bank size also plays a significant role on the bank performance in Bangladesh. The effect of InTA on ROAA and NIM is positive and significant implying that large banks earn higher margin and profit due to benefit of economic of scale on their operations. The results show that one unit increase in InTA increases ROAA by 0.29 units and NIM by 0.84 units which suggests that larger the size of the bank more profitable it will be in Bangladesh. The result is found robust in alternative specification.

Now, turn to the type of the banks effecting on the bank performance in Bangladesh. We have mentioned earlier there are three types of local banks in Bangladesh which are public commercial banks, development bank and private commercial banks. We have used two dummies development bank and private commercial banks and eliminated public bank dummy for avoiding multicolinearity problem and comparing development banks and private commercial banks with public commercial banks. The positive coefficient of D1 and D2 in all models except ROAE for D1 suggests that both development banks and private commercial banks are more profitable and better performed than public commercial banks in Bangladesh.

Now we are discussing the effect of macroeconomic factors on the bank performance. The effect of real GDP growth rate on ROAA and ROAE is significant and negative while it's effect on NIM is insignificant. The result suggests that GDP growth rate is significant determinant of banks' profitability in Bangladesh. The negative coefficient of GDP growth rate further indicates that high productivity is not unfavorable for banking profitability in Bangladesh when we consider ROAA and ROAE as profitability measures. Such condition is the evidence of the volatile condition of the banking sector in Bangladesh which is consistent with the findings of Choon et al. (2012) for Malaysian case. The effect of inflation based on consumer price index is positive and significant on both ROAA and ROAE but the effect is insignificant in case of NIM which is consistent with the finding of Kosmidou et al. (2005) for UK case, Wasiuzzaman and Tarmizi (2010) for Malaysian case. The positive relationship between inflation and profitability supports the theory that inflation provides banks opportunity to adjust interest rate change which may result in revenue generation and increases bank profitability. The real interest rate influences bank performance negatively and insignificantly in all models while the influence of stock market turnover on bank performance is positive and significant in all specifications. The result for all macro economic variables is found consistent and robust in alternative specifications.

As additional analysis, it is evident from GMM results that OLS fixed effect model is misspecified and biased. However, OLS fixed effect model satisfies the criteria of goodness of fit which shows that ROAA is the best measure of profitability based on the value of R-square. The finding is conformed with GMM model with higher coefficient and more significant values.

\section{Conclusion}

The paper investigates the effect of bank specific and macroeconomic determinants on profitability of 299 observations of 35 banks in Bangladesh during 2003 to 2013. The bank specific determinants of the study include credit risk, capital adequacy, liquidity, cost efficiency and logarithm of bank size; and macroeconomic determinants include real GDP growth rate, inflation rate, real interest rate and stock market turnover. Moreover, study considers ROAA, ROAE and NIM as profitability indicators. The novelty of our study includes the analysis of the bank type on the profitability, use of both OLS fixed effect and two step system GMM model considering some econometric issues and give more focus on macroeconomic determinants besides bank specific determinants on profitability.

The results find that credit risk, capital adequacy, cost efficiency and bank size effect banking profitability in Bangladesh significantly. The effect of credit risk and cost efficiency is negative and significant which calls for prudent cost management and efficient credit risk identification, monitoring and controlling is needed for improving the profitability in the country. However, the effect of capital adequacy and bank size on profitability is positive and significant but the effect of liquidity is insignificant. Moreover, the results show that the effect of GDP and real interest rate on profitability is negative but the effect of real interest rate is insignificant. 
Furthermore, it is found that inflation rate and stock market turnover effect the profitability positively where the effect of inflation rate is significant alone. In addition, the results reveal that both development bank and private commercial banks are more profitable than state owned commercial banks in Bangladesh. In further analysis, the findings show that GMM results is more preferred and reliable than OLS fixed effect model and ROAA measures profitability in more better way that ROAE and NIM.

\section{References}

AL-Omar, H., \& AL-Mutairi, A. (2008). Bank-Specific Determinants of Profitability: The case of Kuwait. Journal of Economic and Administrative Sciences, 24(2), 20-34.

Athanasoglou, P. P., Brissimis, S. N., \& Delis, M. D. (2008). Bank-specific, industry-specific and macroeconomic determinants of bank profitability. Journal of International Financial Markets, Institutions and Money, 18(2), 121-136.

Azmat, S., Skully, M., \& Brown, K. (2014). Issuer's choice of Islamic bond type. Pacific-Basin Finance Journal, 28(0), 122-135. http://dx.doi.org/10.1016/j.pacfin.2013.08.008

Berger, A. N. (1995). The relationship between capital and earnings in banking. Journal of Money, Credit and Banking, 432-456.

Chaplinska, A. (2012). Evaluation of the borrower's creditworthiness as an important condition for enhancing the effectiveness of lending operations. Paper presented at the SHS Web of Conferences.

Chen, S. H., \& Liao, C. C. (2011). Are foreign banks more profitable than domestic banks? Home-and host-country effects of banking market structure, governance, and supervision. Journal of Banking \& Finance, 35(4), 819-839. http://dx.doi.org/10.1016/j.jbankfin.2010.11.006

Choon, Y., Thim, C. K., \& Kyzy, B. T. (2012). Performance of Islamic Commercial Banks in Malaysia: An Empirical study. Journal of Islamic Economics, Banking and Finance, 8(2), 67-79.

Chortareas, G. E., Garza-García, J. G., \& Girardone, C. (2012). Competition, efficiency and interest rate margins in Latin American banking. International Review of Financial Analysis, 24, 93-103. http://dx.doi.org/10.1016/j.irfa.2012.08.006

Cubillas, E., \& Suárez, N. (2013). Bank market power after a banking crisis: Some international evidence. The Spanish Review of Financial Economics, 11(1), 13-28. http://dx.doi.org/10.1016/j.srfe.2013.04.001

Fang, Y., Hasan, I., \& Marton, K. (2014). Institutional development and bank stability: Evidence from transition countries. Journal of Banking \& Finance, 39, 160-176. http://dx.doi.org/10.1016/j.jbankfin.2013.11.003

Felix Ayadi, O., Richard, E., Chijoriga, M., Kaijage, E., Peterson, C., \& Bohman, H. (2008). Credit risk management system of a commercial bank in Tanzania. International Journal of Emerging Markets, 3(3), 323-332.

Francis, M. E. (2013). Determinants of commercial bank profitability in Sub-Saharan Africa. International Journal of Economics and Finance, 5(9), 134.

Fu, X., Lin, Y., \& Molyneux, P. (2014). Bank competition and financial stability in Asia Pacific. Journal of Banking \& Finance, 38, 64-77. http://dx.doi.org/10.1016/j.jbankfin.2013.09.012

Hassan, M. K., \& Bashir, A. H. M. (2003). Determinants of Islamic banking profitability. Paper presented at the 10th ERF Annual Conference, Morocco.

Heffernan, S., \& Fu, M. (2008). The determinants of bank performance in China.

Jaffar, M. A., \& Musa, R. (2014). Determinants of Attitude towards Islamic Financing among Halal-certified Micro and SMEs: A Preliminary Investigation. Procedia-Social and Behavioral Sciences, 130, 135-144. http://dx.doi.org/10.1016/j.sbspro.2014.04.017

Kolapo, T. F., Ayeni, R. K., \& Oke, M. O. (2012). Credit risk and commercial banks' performance in Nigeria: A panel model approach. Australian Journal of Business and Management Research, 2(2), 31-38.

Kosmidou, K., Tanna, S., \& Pasiouras, F. (2005). Determinants of profitability of domestic UK commercial banks: panel evidence from the period 1995-2002. Paper presented at the Money Macro and Finance (MMF) Research Group Conference.

Lee, C. C., Hsieh, M. F., \& Yang, S. J. (2014). The relationship between revenue diversification and bank performance: Do financial structures and financial reforms matter? Japan and the World Economy, 29, 18-35. http://dx.doi.org/10.1016/j.japwor.2013.11.002 
Liu, G., Mirzaei, A., \& Vandoros, S. (2014). The impact of bank competition and concentration on industrial growth. Economics Letters, 124(1), 60-63. http://dx.doi.org/10.1016/j.econlet.2014.04.016

Masood, O., \& Ashraf, M. (2012). Bank-specific and macroeconomic profitability determinants of Islamic banks: The case of different countries. Qualitative Research in Financial Markets, 4(2/3), 255-268.

Molyneux, P., Nguyen, L. H., \& Xie, R. (2013). Foreign bank entry in South East Asia. International Review of Financial Analysis, 30, 26-35. http://dx.doi.org/10.1016/j.irfa.2013.05.004

Nguyen, J. (2012). The relationship between net interest margin and noninterest income using a system estimation approach. Journal of Banking \& Finance, 36(9), 2429-2437.

Perera, S., Skully, M., \& Chaudhry, Z. (2013). Determinants of commercial bank profitability: South Asian evidence. Asian Journal of Finance \& Accounting, 5(1), 365-380.

Qin, X., \& Dickson, P. (2012). Commercial Banks Profitability Position: The Case of Tanzania. International Journal of Business and Management, 7(13), 136.

Samad, A. (2004). Performance of Interest-free Islamic banks vis-à-vis Interest-based Conventional Banks of Bahrain. International Journal of Economics, Management and Accounting, 12(2).

Samad, A. (2008). Market structure, conduct and performance: Evidence from the Bangladesh banking industry. Journal of Asian Economics, 19(2), 181-193.

Schaeck, K., \& Cihák, M. (2014). Competition, efficiency, and stability in banking. Financial Management, 43(1), 215-241.

Sufian, F. (2009). Determinants of bank efficiency during unstable macroeconomic environment: Empirical evidence from Malaysia. Research in International Business and Finance, 23(1), 54-77.

Wasiuzzaman, S., \& Gunasegavan, N. U. (2013). Comparative study of the performance of Islamic and conventional banks: The case of Malaysia. Humanomics, 29(1), 43-60.

Wasiuzzaman, S., \& Tarmizi, H. (2010). Profitability of Islamic banks in Malaysia: an empirical analysis. Journal of Islamic Economics, Banking and Finance, 6(4), 53-68.

Zhang, J., Jiang, C., Qu, B., \& Wang, P. (2013). Market concentration, risk-taking, and bank performance: Evidence from emerging economies. International Review of Financial Analysis, 30, 149-157. http://dx.doi.org/10.1016/j.irfa.2013.07.016

\section{Copyrights}

Copyright for this article is retained by the author(s), with first publication rights granted to the journal.

This is an open-access article distributed under the terms and conditions of the Creative Commons Attribution license (http://creativecommons.org/licenses/by/3.0/). 